\title{
SEPARATION OF RYE SECALINS BY A-PAGE
}

\section{Petrovičová Lenka*, Balážová Želmíra, Vivodík Martin, Gálová Zdenka}

Department of Biochemistry and Biotechnology, Faculty of Biotechnology and Food Sciences, Slovak University of Agriculture, Nitra, Slovak Republic

\begin{abstract}
The aim of our study was to evaluate the electrophoretic profiles of secalins of fifteen genotypes of rye (Secale cereale L.), which were obtained by polyacrylamide gel electrophoresis in the presence at $\mathrm{pH} 3.1$ (A-PAGE). Electrophoretic separation of storage proteins was conducted according to the methodology recommended by an international organization ISTA, with some own modifications. Fractions from the preparative separation were pooled in such a way that no components from one pool were present in the others. Doc-It LS software was used to detect and to calculate variability of genotypes within individual rye species.Preparative electrophoresis at low $\mathrm{pH}$ allowed a simple separation of $\gamma 75 \mathrm{k}$-secalins, $\omega$-secalins and $\gamma 40 \mathrm{k}$-secalins from the crude material under non-denaturing conditions. The content of $\gamma 75 \mathrm{k}$-secalins varied in analyzed collection of rye from $22.86 \%$ (variety Čerkascanka tetra) to $53.93 \%$ (genotype Valtické) with an average $39.27 \%$. The proportion of $\omega$-secalins in our samples was in an average $39.27 \%$. The largest percent representation of $\omega$-secalins was proved in variety České (58.68\%) and the lowest part of this subunits was detected in variety Radomske (25.83\%). Our results showed that average representation of $\gamma 40 \mathrm{k}$-secalins was $22.05 \%$, with the highest content in variety Víglašské (32.44\%) overleaf with the lowest part of this fraction was detected in Valtické (8.28\%). The variety of wheat Chinese spring and Marquis were used as standards. Storage proteins consist of three fractions, which are the main part of grain proteins and are used as a marker not only for genetic variability investigation, but also for characterization of genotypes. These pooled fractions could be used as starting material for single polypeptide purification.
\end{abstract}

Keywords: cereals; Secale cereale; electrophoresis; A-PAGE; secalins

\section{Introduction}

Rye (Secale cereale L) is a traditional cereal in Central, Eastern and Northern Europe, where it is used for the production of bread and crispbread and as fodder (Hansen et al., 2003). The cereal proteins contribute to the nutritional value of the diet and they are integral and fundamental part of food components. Nutritionally, they are the good source of energy and its amino acids are essential for growth and maintenance (Horszwald et al., 2009). Functionally, they affect the physicochemical and sensory properties of various foods. Recently published data indicate that rye and rye-based products (including breads) are a good source of lignans, phytosterols and phenolic compounds that are biologically active and posses antioxidant properties (mainly they are good free-radical scavengers, reducing agents, potential complexers of prooxidant metals and quenchers of the singlet oxygen formation) (Zielinski, 2002; Michalska et al., 2007; Horszwald et al., 2009).

*Corresponding author: Lenka Petrovičová, Department of Biochemistry and Biotechnology, Faculty of Biotechnology and Food Sciences, Slovak University of Agriculture, Nitra, Slovak Republic, $\bowtie$ petrovicovalenka22@gmail.com 
Genetic diversity has played a vital role in the success of crop improvement. Knowledge of genetic diversity has been successfully used for efficient germplasm management and utilization, genetic fingerprinting and genotype selection (FAO, 1998; Engles et al., 2002). However, there are many methods for estimating genetic diversity since they provide a simple way of quantifying genetic variation while assessing genotype performance under normal growing environments.

However, morphological traits are limited in number, modified by the environment and may be controlled by epistatic and pleiotropic gene effects (Fufa et al., 2005). The gliadin protein markers, as primary product of gene expression, are not affected by the plant growth environment and can reveal small changes (e.g. mutations) in accessible to visual examinations (Alieva et al., 2012). The objective of our work was to evaluate the electrophoretic profile secalins of rye by A-PAGE.

\section{Materials and methodology}

We analyzed five Czechoslovak, five Czech and five SUN (Union of Soviet Socialist Republics) genotypes of Secale cereale, which we obtained from the Gene Bank of Slovak Republic in Pieštany and Gene Bank of Czech Republic in Prague (Table 1). Secalins fractions were isolated from rye 2-chlorethanol extract. Storage proteins were extracted from the endosperm of mechanical homogenized grains. $10 \mu \mathrm{l}$ of each sample was loaded into polyacrylamide gel. Electrophoretic separation of secalins was conducted by the standard reference electrophoretic method by ISTA (Draper, 1987). Separation was performed using analytical electrophoresis at pH 3.1 (A-PAGE). Electrophoresis was carried out at constant electric current $10 \mathrm{~mA}, 500 \mathrm{~V}, 50 \mathrm{~W}$ for approximately 14 hours.

Table 1 List of 15 rye cultivar, their country of origin and Taxone used for A-PAGE analyses

\begin{tabular}{|c|c|c|}
\hline Genotype & Country of origin & Taxone \\
\hline Valtické & Czechoslovakia & S. cereale L. subsp. cereale var. cereale \\
\hline Keřkovské & Czechoslovakia & S. cereale L. subsp. cereale var. cereale \\
\hline České & Czechoslovakia & S. cereale L. subsp. cereale var. cereale \\
\hline Víglašské & Czechoslovakia & S. cereale L. subsp. cereale var. cereale \\
\hline Breno & Czechoslovakia & S. cereale L. subsp. cereale var. cereale \\
\hline Aventino & Czech Republic & S. cereale L. \\
\hline Selgo & Czech Republic & S. cereale L. subsp. tetraploidum KOBYL \\
\hline Radomske & Czech Republic & S. cereale L. \\
\hline České normální & Czech Republic & S. cereale L. \\
\hline Kŕmne žito & Czech Republic & S. cereale L. \\
\hline Tetra start & Union of Soviet Socialist Republics & S. cereale L. subsp. tetraploidum KOBYL \\
\hline Čerkascanka tetra & Union of Soviet Socialist Republics & S. cereale L. subsp. tetraploidum KOBYL \\
\hline Voschod 1 & Union of Soviet Socialist Republics & S. cereale L. subsp. cereale var. cereale \\
\hline Golubka & Union of Soviet Socialist Republics & S. cereale L. subsp. cereale var. cereale \\
\hline Mnogokoloskaja & Union of Soviet Socialist Republics & S. cereale L. subsp. cereale var. cereale \\
\hline
\end{tabular}


Electrophoreograms were coloured in the mixture containing trichloroacetic acid and Comassie Brilliant Blue R-250. Electrophoretic profiles were visualized in photo device with a black and white camera with a filter and lenses. Gels were evaluated using documentation and evaluation system Doc-It LS Image analysis UVP. We analysed five grain of each variety (Secale cereale). The variety of wheat Chinese spring and Marquis were used as standards. The Doclt-LS software was used for statistical interpretation of the electrophoreograms.

\section{Results and discussion}

Rye is important for breeding purposes and for gene introgression in other cereal species like wheat, as a source of favorable agronomic traits Features such as nutrient efficiency, tolerance of diseases, allowing a reduced usage of pesticides and fertilizers during production. Rye proteins are important for rye bread-making quality and this can be attributed to significant in the content and structure of starch and proteins, which are influences by harvest year and genotype (Hansen et al., 2003, 2004; Ribeiro et al., 2012).

Table 2 Content of protein electrophoretic subfractions in rye genotypes

\begin{tabular}{|l|c|c|c|c|}
\hline Genotype & Country of origin & $\gamma \mathbf{7 5 k}$-secalins & $\omega$-secalins & $\gamma \mathbf{4 0 k}$-secalins \\
\hline Valtické & CSK & 53.93 & 37.78 & 8.28 \\
\hline Keřkovské & CSK & 39.39 & 43.43 & 17.18 \\
\hline České & CSK & 29.60 & 58.68 & 17.71 \\
\hline Víglašské & CSK & 40.33 & 27.22 & 32.44 \\
\hline Breno & CSK & 52.68 & 26.27 & 21.50 \\
\hline Aventino & CZ & 41.46 & 38.79 & 19.74 \\
\hline Selgo & CZ & 44.35 & 30.14 & 25.50 \\
\hline Radomske & CZ & 53.62 & 25.83 & 20.54 \\
\hline České normální & CZ & 25.83 & 47.17 & 27.0 \\
\hline Kŕmne žito & CZ & 37.93 & 40.15 & 21.91 \\
\hline Tetra start & SUN & 35.96 & 41.39 & 22.63 \\
\hline Čerkascanka tetra & SUN & 22.86 & 51.56 & 25.57 \\
\hline Voschod 1 & SUN & 38.22 & 39.65 & 22.13 \\
\hline Golubka & SUN & 30.67 & 42.58 & 26.74 \\
\hline Mnogokoloskaja & SUN & 39.64 & 38.42 & 21,93 \\
\hline Min & & 22.86 & 25.83 & 8.28 \\
\hline Max & & 53.93 & 58.68 & 32.44 \\
\hline X & 39.10 & 39.27 & 22.05 \\
\hline SE, \% & 10.13 & 10.17 & 6.49 \\
\hline VK, \% & 25.92 & 25.91 & 29.43 \\
\hline
\end{tabular}

CSK - Czechoslovakia; CZ - Czech Republic; SUN - Union of Soviet Socialist Republics; min. - minimum; max. maximum; $x$ - note: average; $\sigma(\%)$ - standard deviation; VK (\%)- coefficient of variation 
The nutritional and technological quality of grain is a complex variable related to the chemical composition of grain especially with the percentage representation of individual protein fraction which determines the direction of using grains (rye baking process, pharmaceutical use) (Chňapek et al., 2010).

Within fifteen genotypes of rye $\gamma 75 \mathrm{k}$-secalins, $\omega$-secalins and $\gamma 40 \mathrm{k}$-secalins were identified by electrophoretic spectrum. The content of $\gamma 75 \mathrm{k}$-secalins varied from $22.86 \%$ (variety Čerkascanka tetra) to $53.93 \%$ (genotype Valtické) with an average $39.10 \%$. The proportion of $\omega$-secalins in samples was in an average $39.27 \%$. The largest amount of the subunits was observed in variety České (58.68\%) and the lowest one was detected in variety Radomske (25.83\%). Our results showed that average representation of $\gamma 40 \mathrm{k}$-secalins was $22.05 \%$, with the highest content in variety Víglašské $(32.44 \%)$ overleaf with the lowest part of this fraction was detected in Valtické (8.28\%) (Table 2).

In report Rumbo et al. (2002), the optimization of a preparative electrophoretic method to fractionate secalins is described. Separation was performed in preparative $7 \%$ polyacrylamide gels of $4 \mathrm{~cm}$ length at $\mathrm{pH}$ 3.1. Preparative electrophoresis at low $\mathrm{pH}$ allowed a simple separation of $\gamma$ - and $\omega$-secalins from crude material under nondenaturing conditions.

\section{Conclusions}

The aim of the present work was to describe profiles of storage proteins in fifteen genotypes of Secale cereale by A-PAGE. The methodology by ISTA is a suitable method for differentiation of rye genotypes, while storage proteins were separated very well into to $\gamma 75 \mathrm{k}$-secalins, $\omega$-secalins and $\gamma 40 \mathrm{k}$-secalins. In conclusion, it was shown that preparative electrophoresis at $\mathrm{pH} 3.1$ is a useful methodology for the preparation of purified secalins components and for a study of breadmaking quality of rye.

\section{References}

Aliyeva, A., Ojaghi, J., Mehdiyeva, S. 2012. Electrophoretic Profiles of Gliadin Subunits to Evaluate Genetic Diversity of Azerbaijan Synthetic Branched Spike Wheat Accessions. American-Eurasian J. Agric. \& Environ. Sci., vol. 12, no. 10, p. 1343-1349. DOI: 10.5829/idosi.aejaes.2012.12.10.6680

Draper, S.R. 1987. ISTA variety committee report of the working group for biochemical tests for cultivar identifikation 1983-1986. Seed Science and Technology, vol. 15, p. 431-434. DOI: 10.15258/sst

Engles, J.M. M., Rao, V.R., Brown, A.H.D., Jackson, M.T. 2002. Managing Plant Genetic Diversity. 487 p. ISBN 9780851995229.

FAO. 1998. The States of the World's Plant Genetic Resources for Food and Agriculture. FAO: Rome Italy, p. 510.

Fufa, H., Baenziger, P. S., Beecher, B. S., Dweikat, I., Graybosch R.A., Eskridge, K.M. 2005. Comparison of phenotypic and molecular marker based classifications of hard red winter wheat cultivars. Euphytica, vol. 145, no. 1, p. 133-146. DOI: 10.1007/s10681-005-0626-3

Hansen, H. B., Møller, B., Andersen, S. B., Jørgensen, J. R., Hansen, A. 2004. Grain characteristics, chemical composition and functional properties of rye (Secale cereale L.) as influenced by genotype and harvest year. Journal of Agricultural 122 and Food Chemistry, vol. 52, no. 8, p. 2282-2291. DOI: 10.1021/ issn.0021-8561

Hansen, H. B., Rasmussen, C. V., Bach Knudsen, K. E., Hansen, Å. 2003. Effects of genotype and harvest year on content and composition of dietary fibre in rye (Secale cereale L) grain. Journal of the Science of Food and Agriculture, vol. 83, no. 1, p. 76-85. DOI: 10.1002/jsfa.1284 
Horszwald, A., Troszyńska, A., Del Castillo, M. D., Zieliński, H. 2009. Protein profile and sensorial properties of rye breads. European Food Research and Technology, vol. 229, no. 6, p. 875-886. DOI: 10.1007/ s00217-009-1129-6

Chňapek, M., Gálová, Z., Tomka, M. 2010. Nutričná a technologická kvalita farebných genotypov pšenice letnej formy ozimnej (Triticum aestivum L.). Potravinárstvo, vol. 1, no. 4, p. 20-25.

Michalska, A., Ceglinska, A., Amarowicz, R., Piskula, M. K., Szawara-Nowak, D., Zielinski, H. 2007. Antioxidant contents and antioxidative properties of traditional rye breads. Journal of agricultural and food chemistry, vol. 55, no. 3, p. 734-740. DOI: 10.1021/jf062425w

Ribeiro, M., Seabra, L., Ramos, A., Santos, S., Pinto-Carnide, O., Carvalho, C., Igrejas, G. 2012. Polymorphism of the storage proteins in Portuguese rye (Secale cereale L.) populations. Hereditas, vol. 149, no. 2, p. $72-$ 84. DOI: $10.1111 /$ (issn)1601-5223

Rumbo, M., Margheritis, A., Chirdo, F., Giorgieri, S., Fossati, C., Añón, M. 2002. Fractionation of secalins and hordeins by preparative electrophoresis at acid pH. European Food Research and Technology, vol. 214, no. 3, p. 198-201. DOI: /10.1007/217.1438-2385

Zielinski, H. 2002. Low molecular weight antioxidants in the cereal grains: A review. Polish journal of food and nutrition sciences, vol. 11, no. 1, p. 3-9. 